\title{
Somatotropic axis and concentrate supplementation in grazing dairy cows of genetically diverse origin
}

\author{
T. M. Grala, ${ }^{* 1}$ M. C. Lucy,† C. V. C. Phyn, ${ }^{\star}$ A. J. Sheahan, ${ }^{\star}$ J. M. Lee, ${ }^{\star}$ and J. R. Roche ${ }^{\star}$ \\ *DairyNZ Ltd., Hamilton, New Zealand \\ †Department of Animal Sciences, University of Missouri, Columbia 65211
}

\begin{abstract}
Supplementing pasture-fed dairy cows with concentrates in early lactation was hypothesized to result in an earlier postpartum recoupling of the somatotropic axis in New Zealand (NZ)-type Holstein-Friesian dairy cows than in North American (NA)-type cows. To test this hypothesis, NA $(\mathrm{n}=30)$ and NZ $(\mathrm{n}=30)$ cows were allocated to 1 of 3 supplementation strategies (0, 3 , or $6 \mathrm{~kg}$ of dry matter concentrate/d) for the first 12 wk of lactation in a completely randomized design and a $2 \times 3$ factorial arrangement. Production traits and characteristics of the somatotropic axis were studied at phenotypic, hormonal, and gene expression levels. Milk production and plasma metabolite concentrations were measured weekly, and liver was biopsied in wk 1, 4, 8, and 12 postcalving. North American cows produced more milk and displayed a larger degree of somatotropic axis uncoupling than did NZ cows. This was evident in strain differences in body condition score, blood growth hormone, and insulin-like growth factor-1 concentrations, and hepatic expression of growth hormone receptor-1a. No strain $\times$ diet interactions were observed for any characteristic of the somatotropic axis at either the blood metabolite or gene expression level; however, blood insulin concentrations during wk 7 to 11 postpartum increased with concentrate supplementation in NZ but not NA cows. These results demonstrate that feeding supplements does not result in an earlier recoupling of the somatotropic axis; however, the greater blood insulin concentrations with concentrate feeding in NZ cows from wk 7 may result in an earlier recoupling in this genetic strain, after the period investigated in this study. Further research is required to understand differences in insulin control between these genetic strains.
\end{abstract} Key words: early lactation, nutrient partitioning, supplementation

Received August 29, 2010.

Accepted October 14, 2010.

${ }^{1}$ Corresponding author: talia.grala@dairynz.co.nz

\section{INTRODUCTION}

High-producing dairy cows lose BW and BCS to support milk production during early lactation (Roche et al., 2009). High milk production, even during a period of negative energy balance, is achievable because the somatotropic axis in high-producing cows becomes uncoupled, facilitating nutrient provision from body stores (Lucy, 2008). North American (NA)- and New Zealand (NZ)-type Holstein-Friesian (HF) cows have been reported to exhibit an uncoupled somatotropic axis during early lactation under a rotational grazing system (Lucy et al., 2009). New Zealand cows have undergone different genetic selection pressures compared with NA cows, with a breeding index balanced for production and longevity traits. As a result, somatotropic axis uncoupling occurs to a lesser extent compared with animals of NA genetic ancestry (Lucy et al., 2009). The degree of somatotropic axis uncoupling is physiologically represented during early lactation as a greater loss of $\mathrm{BW}$ and BCS in NA cows (Roche et al., 2006). Peripartum physiological changes lead to a decrease in growth hormone receptor (GHR) expression in the liver, resulting in a liver that fails to respond to growth hormone $(\mathbf{G H})$ in the blood (Lucy et al., 2009). Instead, GH acts on organs that are not GH resistant, such as adipose tissue (Butler et al., 2003). This ensures that nutrients are partitioned toward the production of milk at the expense of tissue reserves. Reduced GHR signaling in the liver also limits the synthesis of IGF-I and results in a lower negative feedback on GH production (Rhoads et al., 2004). Therefore, the uncoupled somatotropic axis is reflected by an excess of GH and a scarcity of IGF-I in blood (Lucy et al., 2009). Gene expression analyses have indicated that GHR transcripts (specifically GHR1a) are reduced in liver tissue peripartum, suggesting the uncoupling of the somatotropic axis is, at least partly, controlled at the gene transcription level (McCarthy et al., 2009).

The duration of early-lactation BCS loss is reportedly reduced in both NZ and NA cows when offered concentrate feed supplements (Roche et al., 2006). New Zealand cows have a greater response to supplementation, gaining more BCS and at a faster rate than their 
NA counterparts (Roche et al., 2006; Macdonald et al., 2008). In addition, concentrations of IGF-I in the blood of NZ cows increased with supplementation, indicative of a GH-responsive liver and thus a recoupled somatotropic axis (Lucy et al., 2009). These results indicate that NZ and NA cows respond differently to supplementation in the recoupling of the somatotropic axis.

Based on these results, it was hypothesized that concentrate supplementation would lead to an earlier recoupling of the somatotropic axis in NZ HF dairy cows compared with NA HF cows. To test this hypothesis, $\mathrm{NA}$ and NZ cows were divided into 3 supplementation strategies consisting of 0,3 , or $6 \mathrm{~kg}$ of DM concentrate/ cow per day during the first 12 wk of lactation. Milk production, BCS, blood metabolites and hormones, and gene expression of key genes in the somatotropic axis were measured over this period.

\section{MATERIALS AND METHODS}

The study was conducted at Lye Farm, DairyNZ (Hamilton, New Zealand; $37^{\circ} 46^{\prime} \mathrm{S} 175^{\circ} 18^{\prime} \mathrm{E}$ ) from July to October 2005. All treatments and measurements were approved by the Ruakura Animal Ethics Committee, Hamilton, New Zealand.

\section{Experimental Design and Treatments}

Fifty-nine multiparous HF dairy cows $(\mathrm{NZ}, \mathrm{n}=30$; $\mathrm{NA}, \mathrm{n}=29)$ were allocated to 1 of 3 feeding treatments in a completely randomized design and a $2 \times 3$ factorial arrangement of treatments. Treatments were imposed for the first 12 wk of lactation. All cows grazed a generous allowance ( $>45 \mathrm{~kg}$ of DM/cow per day, measured to ground level) of fresh pasture, and 4 of the 6 groups (2 from each strain) received either 3 or $6 \mathrm{~kg}$ of DM/ cow per day of a pelleted concentrate. The remaining 2 groups received no concentrates. Treatments were NZ0 $(\mathrm{n}=10), \mathrm{NZ3}(\mathrm{n}=10), \mathrm{NZ6}(\mathrm{n}=10), \mathrm{NA0}(\mathrm{n}=9)$, NA3 $(n=10)$, or NA6 $(n=10)$. Cow allocation ensured that treatments were balanced for age $(5.4 \pm 1.68 \mathrm{yr})$, calving date (July $27 \pm 26.0 \mathrm{~d}$ ), and genetic merit for milk component yield (Harris et al., 1996).

The genetic strains are similar to those described by Roche et al. (2006). Briefly, the cows of NA genetic origin had $>87.5 \%$ NA genetic ancestry; multiparous NA cows were either imported as embryos or were direct descendents of embryos imported. The embryos referred to were imported from the United States and the Netherlands in 1996 by Holland Genetics Ltd. (Arnhem, the Netherlands), for Livestock Improvement Corp., New Zealand, as part of their sire-proving scheme. As such, the NA genetics used in the present experiment represent NA genetics that have been used widely in grazing systems. The primiparous NA cows used were bred in NZ using NA sires available in NZ. The mean EBV of the sires used were obtained from Livestock Improvement Corp. (Hamilton, New Zealand; evaluations in May 2005). The mean EBV for the NA animals were $+1,270 \mathrm{~kg}(\mathrm{SD}=246.4)$ of milk, $+32 \mathrm{~kg}(\mathrm{SD}=$ 7.7) of fat, $+39 \mathrm{~kg}(\mathrm{SD}=6.4)$ of protein, $+93 \mathrm{~kg}$ ( $\mathrm{SD}$ $=12.4)$ of $\mathrm{BW}$, and $-40 \mathrm{~d}(\mathrm{SD}=117.1)$ survival. The NZ cows used in the present experiment were selected from DairyNZ herds on genetic merit for milk production and survival and the proportion of NZ ancestry $(<12.5 \%$ NA genes). The EBV for NZ cows were +820 $\mathrm{kg}(\mathrm{SD}=225.5)$ of milk, $+28.5 \mathrm{~kg}(\mathrm{SD}=6.95)$ of fat, $+28.4 \mathrm{~kg}(\mathrm{SD}=5.90)$ of protein, $+51.9 \mathrm{~kg}(\mathrm{SD}=15.8)$ of $\mathrm{BW}$, and $+324.5 \mathrm{~d}(\mathrm{SD}=79.92)$ survival.

\section{Grazing Management and Supplementary Feeding Treatments}

Cows were rotationally grazed as 1 herd for the duration of the experiment and only returned to the same area when a minimum of 2 leaves had appeared on the majority $(>75 \%)$ of perennial ryegrass tillers (Roche et al., 2006). Cows had access to a fresh allocation of pasture daily. Pasture allowance $(>45 \mathrm{~kg}$ of $\mathrm{DM} / \mathrm{cow}$ per day) was sufficient to ensure unrestricted DMI (up to approximately $25 \mathrm{~kg}$ of $\mathrm{DM} / \mathrm{d}$ ) of fresh pasture in unsupplemented cows. Pasture was of high quality throughout the experimental period $(\mathrm{CP}=22.4 \pm$ $2.64 \%$ DM; OM digestibility $=82.6 \pm 1.42 \% \mathrm{DM}$; NDF $=48.3 \pm 4.91 \% \mathrm{DM} ; \mathrm{ADF}=22.5 \pm 1.54 \% \mathrm{DM}$; lipid $=4.3 \pm 0.12 \% \mathrm{DM} ; \mathrm{NSC}=15.7 \pm 3.94 \% \mathrm{DM} ; \mathrm{ME}=$ $12.4 \pm 0.40 \mathrm{MJ} / \mathrm{kg}$ of $\mathrm{DM})$.

A flat rate of either 3 or $6 \mathrm{~kg}$ of DM of concentrates/d (32\% crushed barley, $60 \%$ crushed corn, $2 \%$ wheat middlings, $6 \%$ molasses; $\mathrm{CP}=12.9 \pm 3.04 \% \mathrm{DM}$; $\mathrm{NDF}=$ $11.5 \pm 1.49 \% \mathrm{DM} ;$ lipid $=2.8 \pm 0.25 \% \mathrm{DM} ; \mathrm{NSC}=$ $65.1 \pm 2.12 \% \mathrm{DM}$ ) was fed individually to the appropriate cows. Concentrate allocation was split equally in 2 feeds daily during milking. For 15 d precalving, all cows were offered $2 \mathrm{~kg}$ of DM concentrate/d. Following calving, the NZ3 and NA3 cows received $3 \mathrm{~kg}$ of DM concentrate/d, and the NZ6 and NA6 cows were stepped up to $6 \mathrm{~kg}$ of DM concentrate/d over the following $4 \mathrm{~d}(0.75 \mathrm{~kg}$ of DM concentrates/d).

\section{Measurements}

Individual milk yields were recorded daily (GEA Farm Technologies, Oelde, Germany). Milk fat, CP, and lactose concentrations were determined by MilkoScan (Foss Electric, Hillerød, Denmark) on individual morning and afternoon aliquot samples collected on 1 d/wk. Body weights and BCS were determined weekly 
following the morning milking. Body condition score was assessed on a 10-point scale, where 1 was emaciated and 10 was obese (Roche et al., 2004). These scores can be converted to the 5-point scale of Wildman et al. (1982) using the regression equation (USA $=1.5$ $+0.32 \mathrm{NZ}$ ) generated by Roche et al. (2004). Milk $\mathrm{NE}_{\mathrm{L}}$ was calculated as $\mathrm{NE}_{\mathrm{L}}(\mathrm{MJ} / \mathrm{kg})=4.186 \times[(0.0929 \times$ fat \% $)+(0.0547 \times \mathrm{CP} \%)+(0.0395 \times$ lactose \% $)]$ (NRC, 2001) and 4\% FCM was calculated as $4 \%$ FCM $=(0.4 \times \mathrm{kg}$ of milk $/ \mathrm{d})+(15 \times \mathrm{kg}$ of fat $/ \mathrm{d})($ Gaines and Davidson, 1923).

\section{Blood Sampling and Analyses '1of Hormone Concentrations}

Blood was sampled on the same $1 \mathrm{~d}$ every week; a 10-mL evacuated blood tube (140 IU of sodium heparin) was collected from each cow by coccygeal venipuncture before the morning milking (approximately $0730 \mathrm{~h})$. Following centrifugation $(1,120 \times g, 12 \mathrm{~min}$, $4^{\circ} \mathrm{C}$ ), plasma was frozen and stored at $-20^{\circ} \mathrm{C}$ awaiting analysis. Analyses for NEFA (colorimetric method) and glucose (hexakinase method) were performed on a Hitachi 717 analyzer (Roche, Basel, Switzerland) at $30^{\circ} \mathrm{C}$ by Alpha Scientific Ltd., Hamilton, New Zealand. The inter- and intraassay CV were $<2 \%$ for NEFA and glucose. Growth hormone (Downing et al., 1995), IGF1 (Gluckman et al., 1983), insulin (Hales and Randle, 1963), and leptin (Blache et al., 2000) were measured in duplicate by double-antibody RIA with inter- and intraassay $\mathrm{CV}$ of $<6 \%$.

\section{Tissue Sampling}

Liver tissue was collected 4 times relative to parturition. The first sample was collected 1 wk after calving, and subsequent samples were collected on wk 4, 8, and 12. Liver tissue was sampled as per Lucy et al. (2009). In brief, an area in the 11th intercostal space was clipped and cleansed. Local anesthetic was administered and the skin penetrated with a scalpel. Samples of approximately $100 \mathrm{mg}$ each were collected using a liver biopsy needle and immediately placed in screw-capped microcentrifuge tubes and frozen in liquid nitrogen. Samples were stored at $-80^{\circ} \mathrm{C}$ until RNA extraction.

\section{Extraction of RNA and cDNA Synthesis}

Liver biopsies of $30 \mathrm{mg}$ were homogenized using FastPrep Lysing Matrix D tubes in a FastPrep instrument (MP Biomedicals, Solon, OH). Total cellular RNA was extracted from homogenized liver samples using a Qiagen RNeasy kit (Qiagen, Hilden, Germany) and then treated with DNase (Ambion DNA-free kit; Ambion,
Austin, TX). The RNA quantity was determined by spectrophotometry in a NanoDrop ND-1000 instrument (NanoDrop Technologies, Wilmington, DE). The RNA integrity was confirmed using the Agilent 2100 Bioanalyzer with a RNA 6000 Nano LabChip kit (Agilent Technologies, Palo Alto, CA). The RNA samples were stored at $-80^{\circ} \mathrm{C}$.

One microgram of each RNA sample was used for cDNA synthesis using the Invitrogen Superscript III Supermix kit (Invitrogen Corp., Carlsbad, CA). Total RNA was reverse-transcribed using a final concentration of $27 \mu M$ of random pentadecamer primers. Reverse transcriptase negative controls also were generated. The cDNA plates were stored at $-20^{\circ} \mathrm{C}$.

\section{Quantitative PCR and mRNA Analyses}

Transcripts representing all isoforms of GHR, GHR1a, IGF-I, insulin receptor b (IRB), IGF acidlabile subunit (IGFALS), IGF binding protein 3 (IGFBP3), thyroid-responsive hormone (THRSP) and MID1 interacting protein 1 (MID1IP1) were analyzed with quantitative PCR (qPCR). Quantitative PCR was performed with a Roche real-time PCR master mix (Lightcycler 480 Probes Master) and Roche Universal Probe Library assays analyzed on the Roche Lightcycler 480 (Roche Diagnostics, Mannheim, Germany). Assays to publicly available bovine gene sequences (NCBI; http://www.ncbi.nlm.nih.gov/gene) were designed using Roche Universal Probe Library design software. Assays were designed to span an intron-exon boundary to prevent amplification of genomic DNA, except for IGFALS, which consisted of only 1 exon. The primer sequences are presented in Table 1. The qPCR reaction volume was $10 \mu \mathrm{L}$, consisting of $0.5 \mu M$ of each primer and $0.1 \mu M$ of probe. Standard cycling conditions were used $\left(95^{\circ} \mathrm{C}\right.$ for $10 \mathrm{~min},\left[95^{\circ} \mathrm{C}\right.$ for $10 \mathrm{~s}, 60^{\circ} \mathrm{C}$ for $\left.30 \mathrm{~s}\right] \times$ 50 cycles, $40^{\circ} \mathrm{C}$ for $40 \mathrm{~s}$ ).

To quantify gene expression, cDNA was diluted 100fold for all genes except GHR1a and IGFBP3, where cDNA was diluted 10-fold. Each qPCR run included a no-template control with water added instead of cDNA, a reverse transcriptase negative control for each gene, and 3 inter-run calibrators. Inter-run calibrators were necessary as the number of samples required multiple plates to be used for each gene (Hellemans et al., 2007). Triplicate measurements were performed for all samples and standard curves. Possible endogenous control genes were tested across all samples for each tissue type to determine the most suitable gene for normalization of qPCR data in the current study. Three genes (peptidylprolyl isomerase A, PPIA; ribosomal protein S15a, RPS15a; and ubiquitously expressed transcript, UXT) were selected based on their previous use as endogenous 
Table 1. Characteristics of gene-specific quantitative PCR assays

\begin{tabular}{|c|c|c|c|c|c|c|}
\hline Gene $^{1}$ & $\begin{array}{l}\text { GenBank } \\
\text { accession no. }\end{array}$ & $\begin{array}{l}\text { Primer } \\
\text { direction }\end{array}$ & Primer sequence $^{2}$ & $\begin{array}{l}\text { UPL probe } \\
\text { number }^{3}\end{array}$ & $\begin{array}{l}\text { Amplicon } \\
\text { size, bp }\end{array}$ & $\begin{array}{c}\text { Average PCR } \\
\text { efficiency }^{4}\end{array}$ \\
\hline \multicolumn{7}{|c|}{ Endogenous control genes } \\
\hline PPIA & NM_178320 & Forward & GTCAACCCCACCGTGTTCT & 152 & 99 & 1.83 \\
\hline RPS15a & NM 001037443 & $\begin{array}{l}\text { Reverse } \\
\text { Forward }\end{array}$ & $\begin{array}{l}\text { TTCTGCTGTCTTTGGAACTTTG } \\
\text { TCAGCCCTAGATTTGATGTGC }\end{array}$ & 32 & 104 & 1.86 \\
\hline & & Reverse & GCCAGCTGAGGTTGTCAGTA & & & \\
\hline \multicolumn{7}{|c|}{ Genes of interest } \\
\hline GHRtot & NM_176608 & $\begin{array}{l}\text { Forward } \\
\text { Reverse }\end{array}$ & $\begin{array}{l}\text { CCATGGTTCTTAATTATTATCTTTGGA } \\
\text { TGGGGGTAGAATCAGCATCT }\end{array}$ & 117 & 105 & 1.73 \\
\hline GHR1a & AY748827 & $\begin{array}{l}\text { Forward } \\
\text { Reverse }\end{array}$ & $\begin{array}{l}\text { TCCAGCCTCTGTTTCAGGAG } \\
\text { GCTGCCAGAGATCCATACCT }\end{array}$ & 120 & 64 & 1.84 \\
\hline IGF-I & NM_001077828 & $\begin{array}{l}\text { Forward } \\
\text { Reverse }\end{array}$ & $\begin{array}{l}\text { ATGTACTGCGCGCCTCTC } \\
\text { CCCTCTACTTGTGTTCTTCAAATG }\end{array}$ & 104 & 114 & 1.86 \\
\hline IGFALS & NM_001075963.1 & $\begin{array}{l}\text { Forward } \\
\text { Reverse }\end{array}$ & $\begin{array}{l}\text { GCGCAGGTGATGTTGTTGTA } \\
\text { GGCAGAGGGTAACGACGAC }\end{array}$ & 28 & 60 & 1.90 \\
\hline IGFBP3 & NM_174556 & $\begin{array}{l}\text { Forward } \\
\text { Reverse }\end{array}$ & $\begin{array}{l}\text { GCGCCCTTACCTGCTACC } \\
\text { CAGCCTGGTTCTCTGTGCT }\end{array}$ & 114 & 86 & 1.80 \\
\hline IRB & AJ320235 & $\begin{array}{l}\text { Forward } \\
\text { Reverse }\end{array}$ & $\begin{array}{l}\text { TGCACAACGTGGTTTTCATC } \\
\text { GTTTCCTCGAAGGCCTAGC }\end{array}$ & 124 & 75 & 1.73 \\
\hline MID1IP1 & NM_001076383 & $\begin{array}{l}\text { Forward } \\
\text { Reverse }\end{array}$ & $\begin{array}{l}\text { GGAGATCGGCTTCAGCAAT } \\
\text { TTAAGGAAAGAGAGAGGGTGAGATA }\end{array}$ & 72 & 96 & 1.89 \\
\hline THRSP & AY656814 & $\begin{array}{l}\text { Forward } \\
\text { Reverse }\end{array}$ & $\begin{array}{l}\text { ATGGGACAGGCCGTGTAG } \\
\text { TGCACCATGTCTTCATCACA }\end{array}$ & 8 & 71 & 1.89 \\
\hline
\end{tabular}

${ }^{1}$ PPIA = peptidylprolyl isomerise A (cyclophilin A); RPS15a = ribosomal protein S15a; GHRtot = growth hormone receptor; GHR1a = growth hormone receptor 1a; IGFBP3 = IGF binding protein 3; IRB = insulin receptor b; MID1IP1 = MID1 interacting protein 1; THRSP $=$ thyroid-responsive hormone.

${ }^{2}$ Primer sequences are shown $5^{\prime}$ to $3^{\prime}$.

${ }^{3} \mathrm{UPL}=$ Universal Probe Library.

${ }^{4}$ The PCR efficiency was averaged over 3 quantitative PCR reactions. 
control genes in the tissue of interest (Grala et al., 2010) and their expression measured using qPCR. The suitability of each gene was determined using the statistical algorithms GeNorm (Vandesompele et al., 2002) and Normfinder (Andersen et al., 2004).

Roche Lightcycler 480 software was used to perform quantification analysis of gene expression using the relative standard curve, second-derivative maximum analysis method, a nonlinear regression line method. A 6-point relative standard curve of serial dilutions of cDNA was used with an estimated starting concentration of 1.0 and a final concentration of $1.6 \mathrm{E}-03$. The Roche Lightcycler 480 Software was used to perform advanced relative quantification analysis of gene expression. Relative quantification was performed using the normalization factor of the 2 most stably expressed genes across the treatments and time points identified through GeNorm and Normfinder analysis. These endogenous control genes were PPIA and RPS15a. Normalization factors were calculated by taking the geometric mean of the 2 genes for each sample. After normalization, the geometric mean of the inter-run calibrators was calculated for each plate and applied to each sample.

\section{Calculations and Statistical Analysis}

Milk production and metabolite data were analyzed with a repeated measurement analysis method using the procedure AREPMEASURES in GenStat 8.2 (VSN International, Hemel Hempstead, UK). The means of each week (1 to 12) were calculated for each cow as a summary measure and analyzed using linear models including the factors strain, diet and their interactions.

RNA was successfully extracted from 200 liver biopsies; 40 samples were too small to be used or were degraded. Final numbers for each strain were $96 \mathrm{NZ}$ liver samples $(0 \mathrm{~kg} \mathrm{DM} / \mathrm{d}, \mathrm{n}=33 ; 3 \mathrm{~kg} \mathrm{DM} / \mathrm{d}, \mathrm{n}=31$; and $6 \mathrm{~kg} \mathrm{DM} / \mathrm{d}, \mathrm{n}=32)$ and $104 \mathrm{NA}$ liver samples $(0$ $\mathrm{kg} \mathrm{DM} / \mathrm{d}, \mathrm{n}=36 ; 3 \mathrm{~kg} \mathrm{DM} / \mathrm{d}, \mathrm{n}=36 ; 6 \mathrm{~kg} \mathrm{DM} / \mathrm{d}, \mathrm{n}$ $=32$ ). Data collected were analyzed after $\log _{10}$ transformation (because of heterogeneity of the variance) using a repeated measures analysis method. Mixed models were fitted using REML in GenStat11.1 (VSN International). A compound symmetry covariance structure was used to model the repeated time measurements within cows. Data are presented as least squares means and standard error of the difference between the means.

Correlations were performed between IGF-I measures in the blood and mRNA, in addition to IGF-I and GHR1a mRNA amounts. Data were graphed to ensure outliers were identified, and when no outliers were observed correlations were calculated. These correlations were calculated for each time point to ensure the correlation coefficient was not related to time differences.

\section{RESULTS}

\section{Milk Production, BW, and BCS}

Mean milk and component yield, milk composition, BCS, and BW data are presented in Table 2. North American cows produced a greater amount $(P<0.05)$ of a more dilute $(P<0.05)$ milk than NZ HF. Consequently, milk from $\mathrm{NZ}$ cows had a greater $\mathrm{NE}_{\mathrm{L}}$ per kilogram. Energy-corrected milk and 4\% FCM yields were not affected by genetic strain; nonetheless, NA cows tended to produce a greater total yield of protein $(P=0.10)$ and lactose $(P=0.06)$ during the first 84 DIM. Milk fat yield was not affected by treatment.

Concentrate supplementation resulted in a linear increase $(P<0.05)$ in the yield of milk and milk components, including 4\% FCM and ECM. However, protein percentage was the only component that increased $(P<0.01)$ with concentrate supplementation $(0.02$ to $0.04 \% / \mathrm{kg}$ of DM concentrate); fat and lactose percentage were not affected by treatment. As a result, milk $\mathrm{NE}_{\mathrm{L}}$ was not affected by concentrate supplementation.

On average, NA HF cows were heavier $(P<0.05)$, but thinner $(P<0.001)$ than NZ HF cows during the first 84 DIM. Concentrate supplementation did not affect either of these parameters, irrespective of genetic strain. Body condition score change was not affected by supplementation or strain. No strain $\times$ diet interaction effects were evident (Table 2.)

\section{Plasma Metabolite Concentrations}

The effects of genetic strain and supplementation regimen on blood metabolite data over the first $12 \mathrm{wk}$ of lactation are presented in Figures 1 and 2, respectively. Circulating GH concentrations were greater $(P$ $<0.001)$ and IGF-I concentrations less $(P<0.01)$ in NA cows. North American cows also had consistently lower leptin concentrations $(P<0.05)$ than their NZ HF counterparts. Concentrations of glucose, insulin, and NEFA were not affected by genetic strain.

Growth hormone $(P<0.05)$, IGF-I $(P<0.05)$ and glucose $(P<0.01)$ concentrations were affected in a nonlinear manner by concentrate supplementation, with both concentrate-fed groups having lesser GH but greater IGF-I and glucose concentrations of these circulating factors than the unsupplemented group, but supplement amount had no effect. Plasma leptin, insulin, and NEFA concentrations were not affected by supplementation. Interestingly, plasma insulin concentrations from wk 7 onward indicated strain $\times$ diet interactions $(P<0.05)$, as NZ cows receiving supplements had greater concentrations than unsupplemented NZ HF; but NA cows had no insulin response to supple- 
mentation (Supplementary Table 1; available online at http://www.journalofdairyscience.org/). None of the other metabolites measured indicated strain $\times$ diet interactions (Supplementary Table 1).

\section{Liver mRNA Expression}

The effect of genetic strain and supplementation regimen on gene expression data over the first 12 wk of lactation are presented in Figures 3 and 4, respectively. New Zealand cows had greater transcription of GHR1a $(P<0.05)$ and THRSP $(P<0.001)$, but less transcription of IGFBP3 $(P<0.05)$. Although the expression of GHR1a was consistently greater in NZ cows over the 12 wk of early lactation (Figure 3B), THRSP expression differences were no longer evident by wk 12 (Figure $3 \mathrm{G})$. The majority of the IGFBP3 expression difference between NA and NZ HF can be accounted for in wk-4 samples, as this time point was the only week in which IGFBP3 expression was greater in NA cows (Figure $3 \mathrm{E})$. Gene expression of all isoforms of GHR, IGF-I, IGFALS, IRB, or MID1IP1 was not affected by genetic strain.

Supplementation linearly increased THSRP gene expression $(P<0.01$; Figure $4 \mathrm{G})$; however, MID1IP1 gene expression was greater in both groups of supplemented cows compared with unsupplemented cows, and the supplement amount had no effect $(P<0.001$; Figure $4 \mathrm{H})$. Concentrate supplementation had no effect on the expression of the other genes considered.

Expression of all the genes tested increased over time, with the exception of IRB, the expression of which decreased over the 12 wk of this study. No strain $\times$ diet interactions were evident in gene transcription assays evaluated in this study (Supplementary Table 2; available online at http://www.journalofdairyscience.org/).

Correlations were performed between the blood and mRNA measures of IGF-I, as well as between the IGF-I and GHR1a mRNA data. A correlation between blood and mRNA IGF-I was not seen at wk $1\left(\mathrm{r}^{2}=0.003\right.$; $P=0.71$ ); however, correlations were seen in wk 4,8 , and $12\left(\mathrm{r}^{2}=0.10, P<0.02 ; \mathrm{r}^{2}=0.11, P<0.04 ; \mathrm{r}^{2}=\right.$ $0.29, P<0.002$, respectively). Correlations were seen in every week between mRNA concentrations of IGF-I and GHR1a ( $1 \mathrm{wk}, \mathrm{r}^{2}=0.41, P<0.001 ; 4 \mathrm{wk}, \mathrm{r}^{2}=$ $0.48, P<0.001 ; 8 \mathrm{wk}, \mathrm{r}^{2}=0.42, P<0.001 ; 12 \mathrm{wk}, \mathrm{r}^{2}$ $=0.21, P<0.001)$.

\section{DISCUSSION}

Cows with NA genetics produced greater volumes of milk, with lower component percentages compared with NZ HF. Plasma GH concentrations were greater and IGF-I concentrations less in NA cows also. Cows of

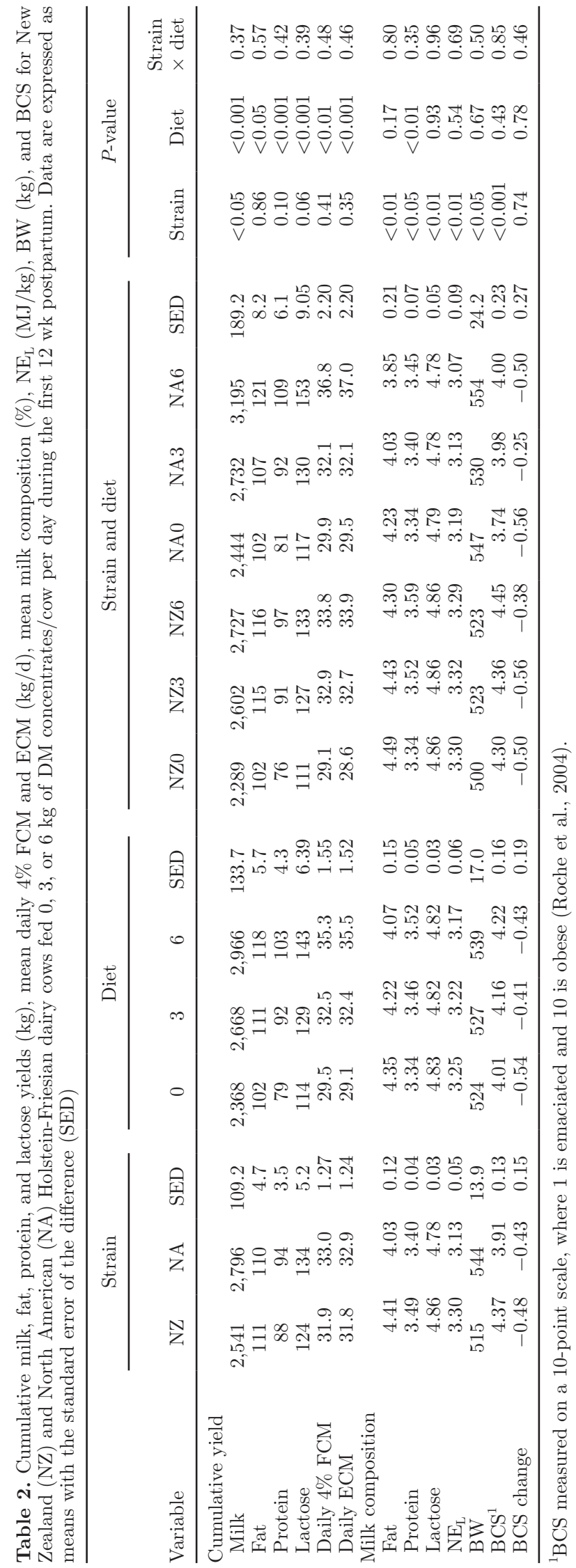


A

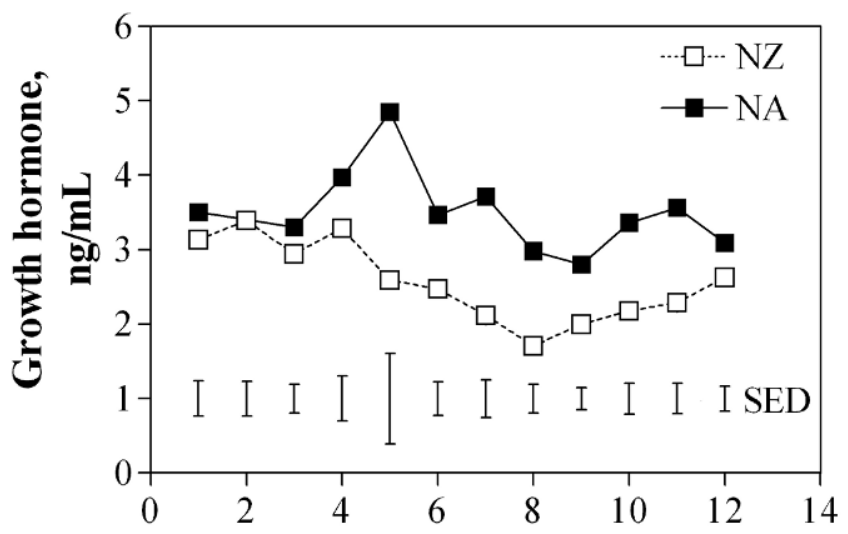

C

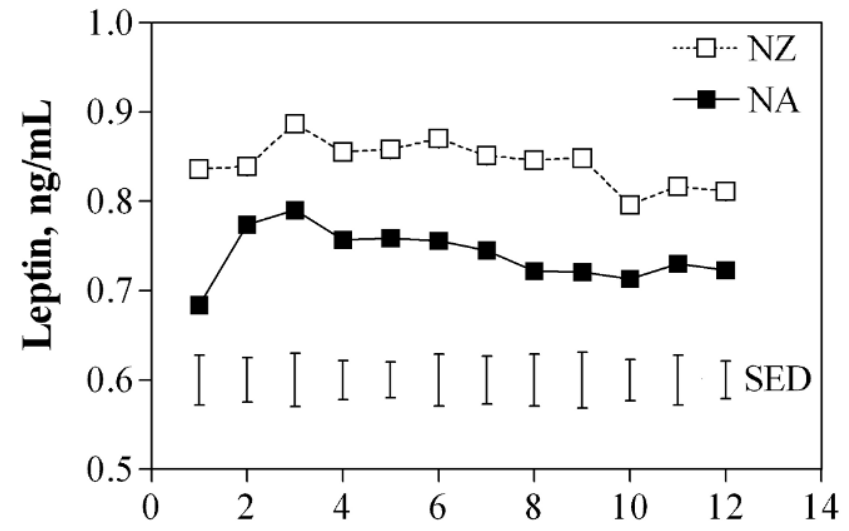

E

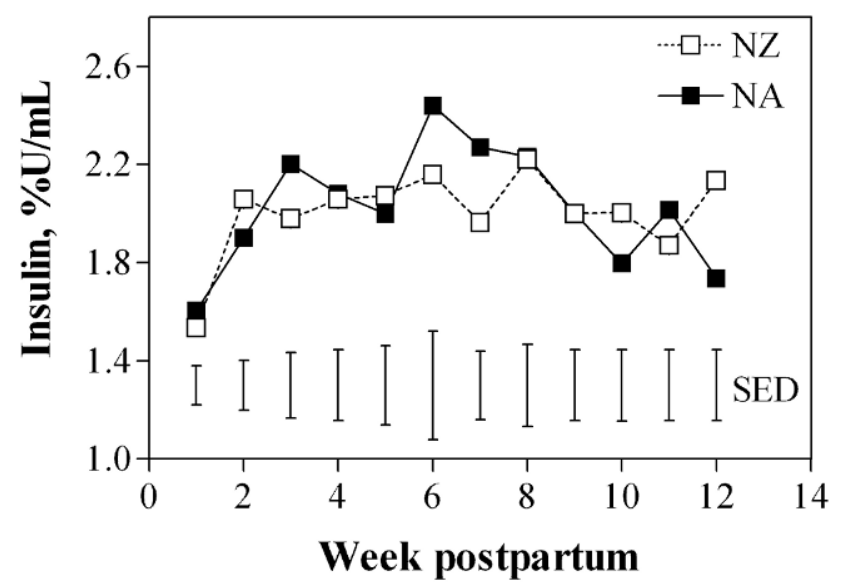

B

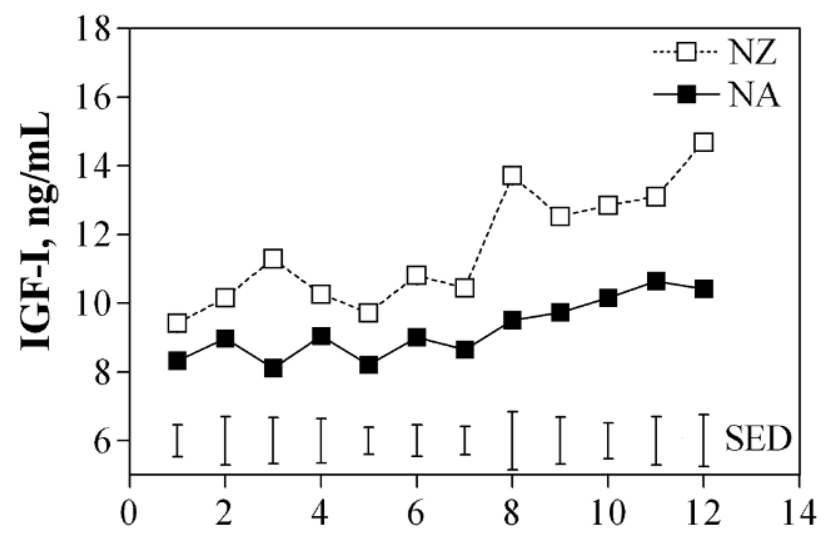

D

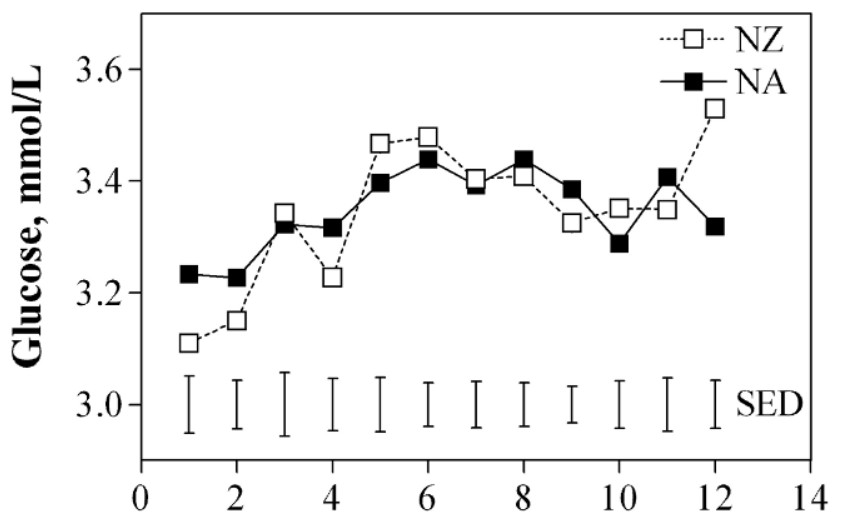

F

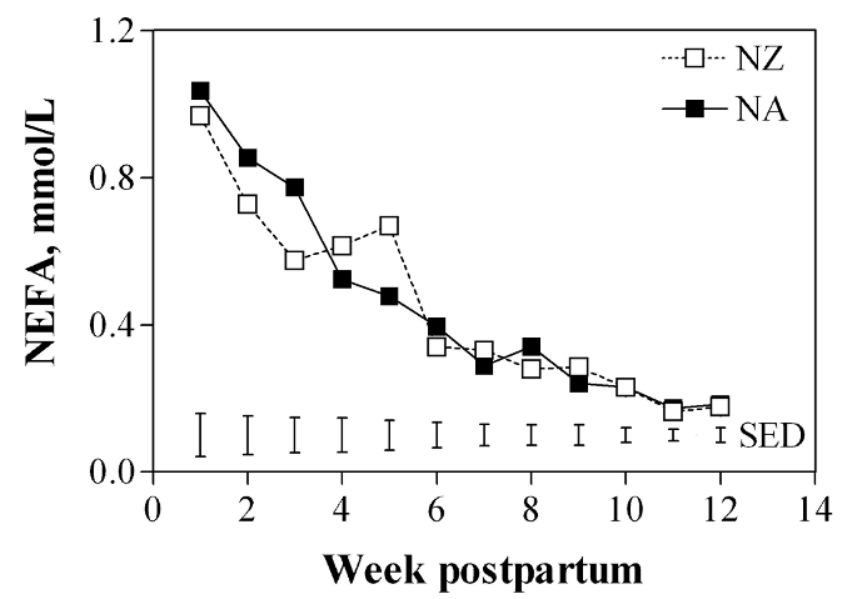

Figure 1. Least squares means and standard error of the difference (SED) for plasma (A) growth hormone, (B) IGF-I, (C) leptin, (D) glucose, (E) insulin, and (F) NEFA during the first 12 wk postpartum in New Zealand Holstein-Friesian (NZ; n = 30) or North American HolsteinFriesian cows $(\mathrm{NA} ; \mathrm{n}=29)$.

NZ origin had greater BCS, plasma leptin, and expression of the THRSP and MID1IP1 genes, whereas NA cows had greater IGFBP3 expression. Supplementation resulted in a linear increase in milk yield and yield of milk components, as well as lower circulating GH and higher circulating IGF-I concentrations. Supplemented 
A

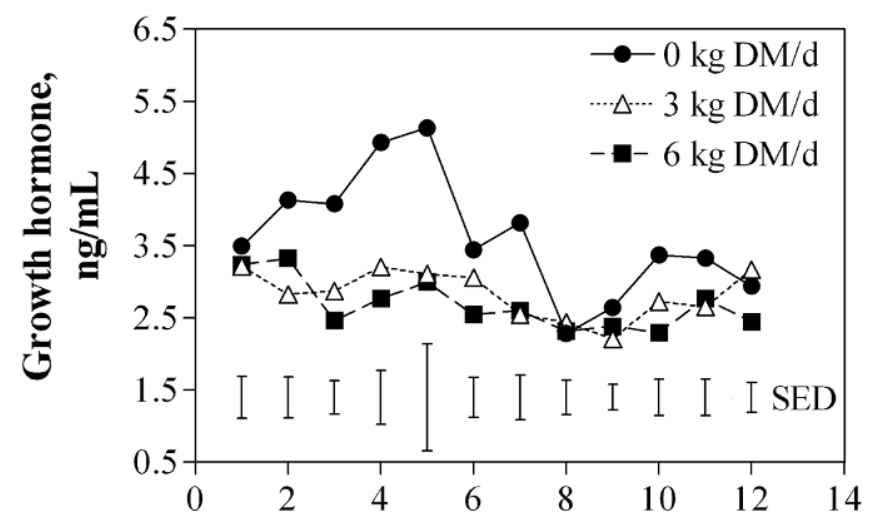

C

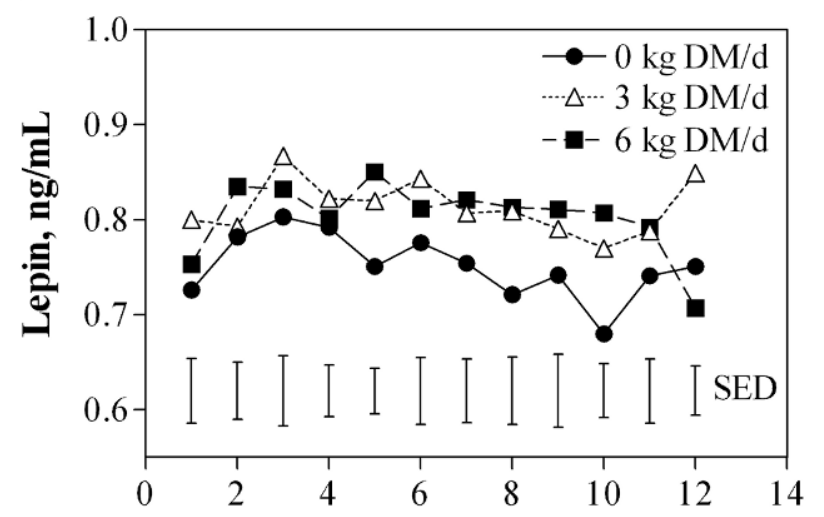

$\mathrm{E}$

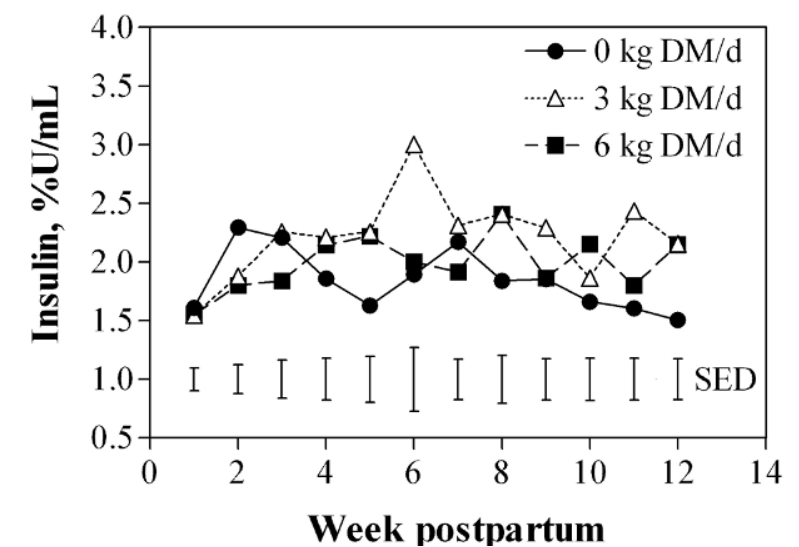

B

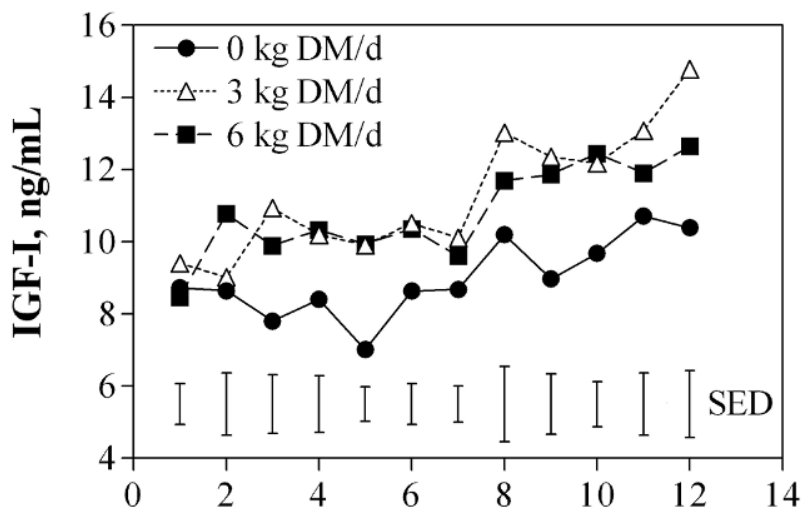

D

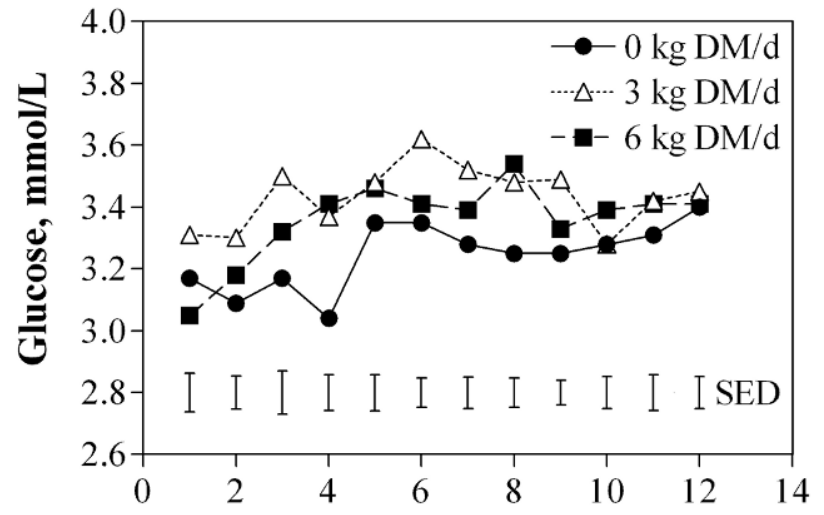

$\mathrm{F}$

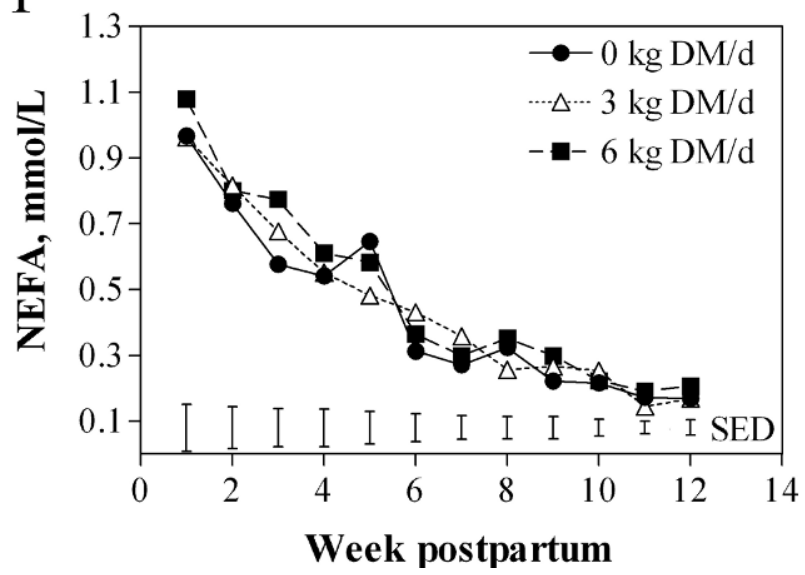

Figure 2. Least squares means and standard error of the difference (SED) for plasma (A) growth hormone, (B) IGF-I, (C) leptin, (D) glucose, (E) insulin, and (F) NEFA during the first 12 wk postpartum in cows fed 1 of 3 supplementation strategies: $0(n=19), 3(\mathrm{n}=20)$, or 6 $(\mathrm{n}=20) \mathrm{kg}$ of DM concentrates/cow per day.

groups did not differ in their concentrations of glucose or MID1IP1 gene expression; however, glucose concentrations, MID1IP1, and THRSP expression were greater in supplemented cows compared with unsupplemented cows.

\section{NZ and NA Cows Demonstrate Somatotropic Axis Uncoupling During Early Lactation}

Somatotropic axis uncoupling is characterized by low $\mathrm{GH}$ receptor expression in the liver, and hence reduced 

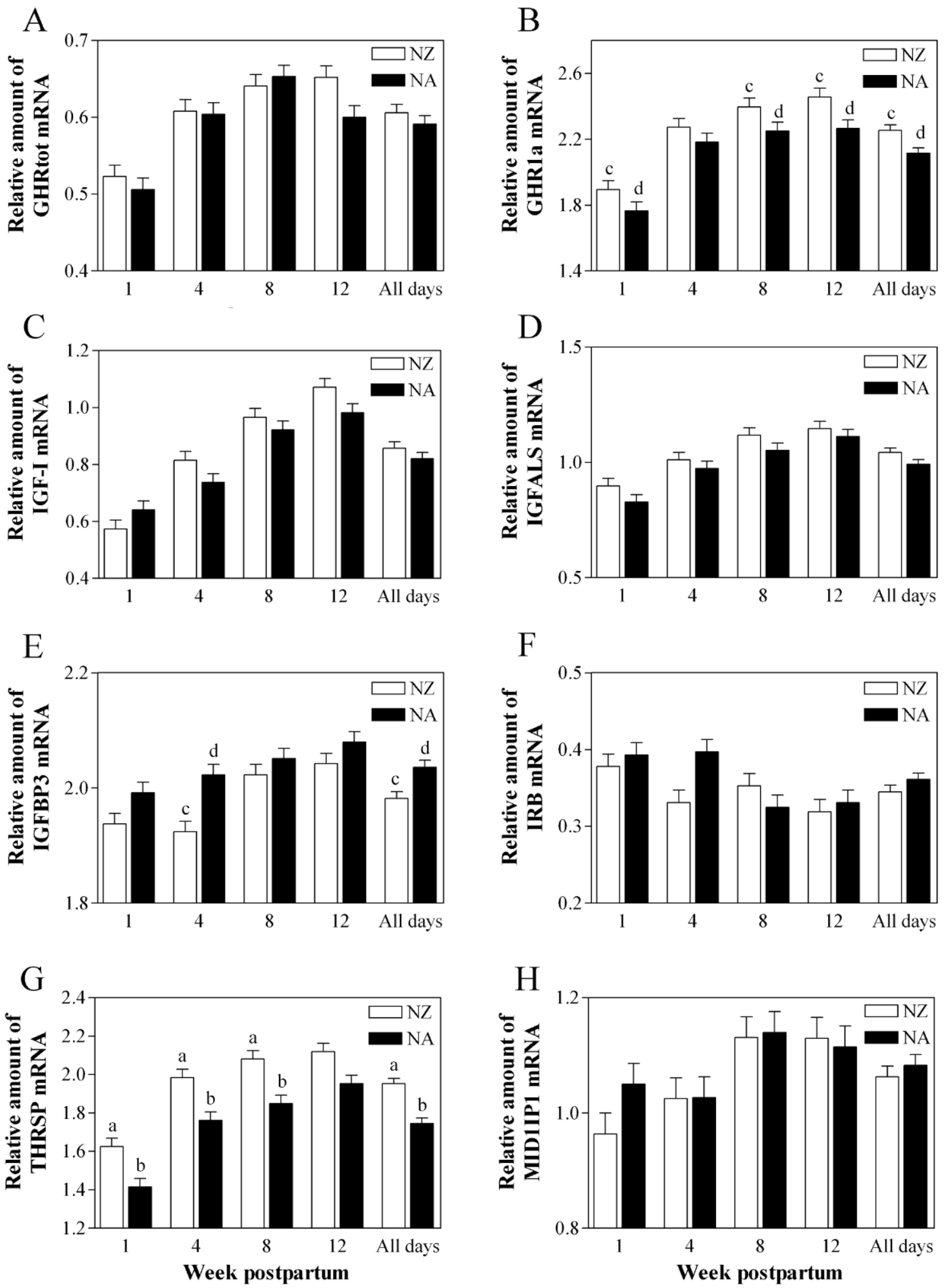

Figure 3. Least squares means and standard error of the difference (SED) for the relative amount of liver mRNA for (A) growth hormone receptor (GHR) total, (B) GHR1a, (C) IGF-I, (D) IGF acid labile subunit (IGFALS), (E) IGF binding protein 3 (IGFBP3), (F) insulin receptor b (IRB), (G) thyroid hormone responsive (THRSP), and (H) MID1 interacting protein 1 (MID1IP1), during wk 1, 4, 8, and 12 after calving and across all sampling points (all days). Cows were New Zealand Holstein-Friesian (NZ; $\mathrm{n}=30$ ), or North American Holstein-Friesian $(\mathrm{NA} ; \mathrm{n}=29)$. Data were adjusted for peptidylprolyl isomerise A (PPIA) and ribosomal protein S15a (RPS15a) expression and logarithmically transformed.

${ }^{\mathrm{a}, \mathrm{b}}$ Bars with different letters are different at $P<0.001$; ${ }^{\mathrm{c}, \mathrm{d}}$ bars with different letters are different at $P<0.05$. 

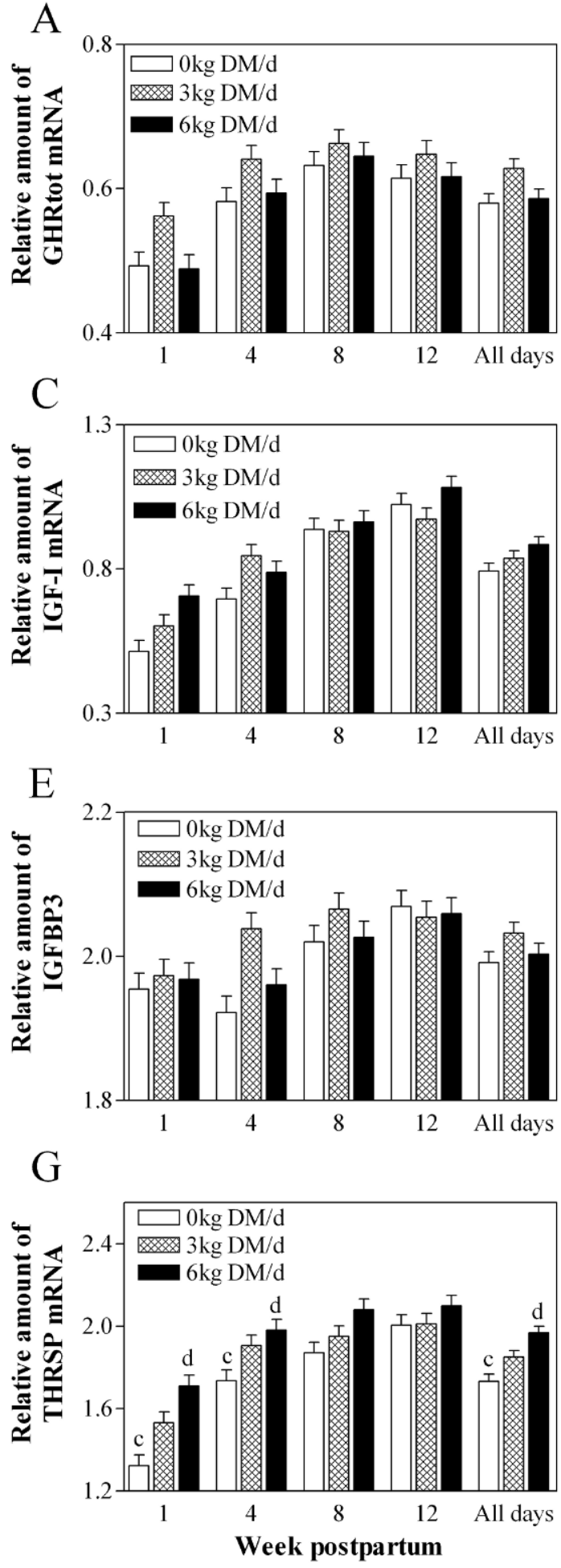
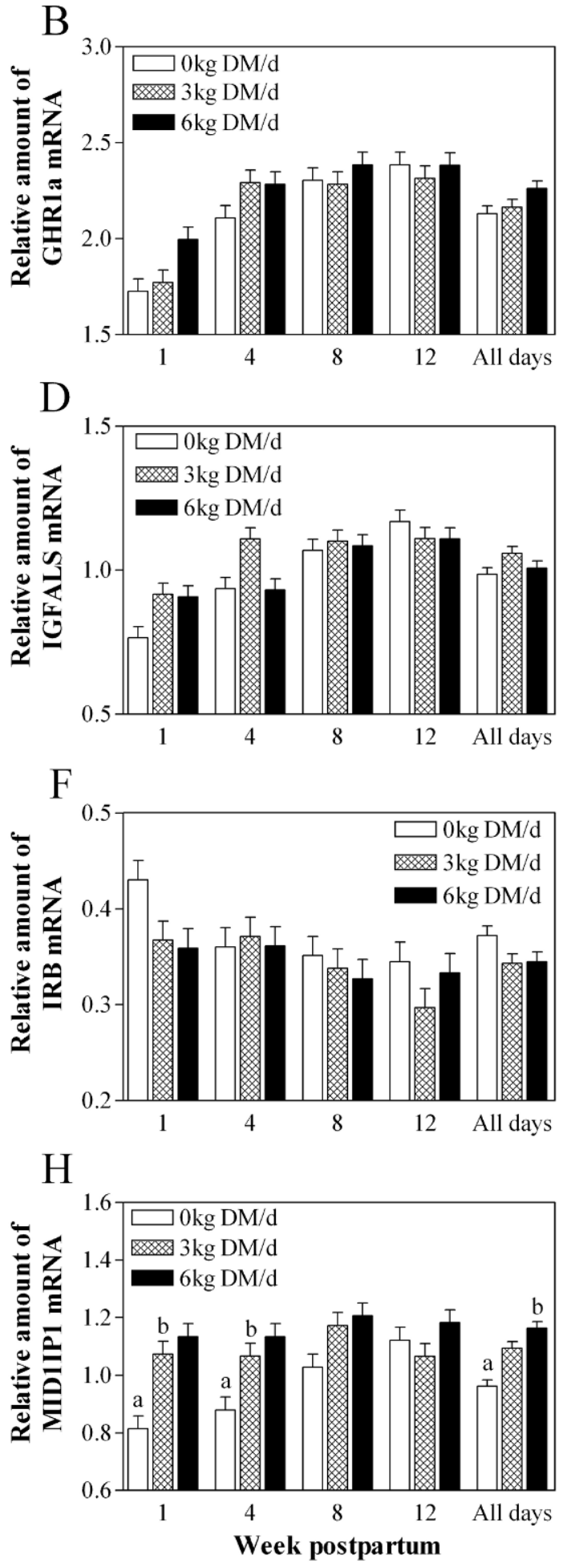

Figure 4. Least squares means and standard error of the difference (SED) for the relative amount of liver mRNA for (A) growth hormone receptor (GHR) total, (B) GHR1a, (C) IGF-I, (D) IGF acid labile subunit (IGFALS), (E) IGF binding protein 3 (IGFBP3), (F) insulin receptor b (IRB), (G) thyroid hormone responsive (SPOT14 homolog, rat; THRSP), and (H) MID1 interacting protein 1 (MID1IP1), during wk 1, 4, 8, and 12 after calving and across all sampling points (all days). Cows were fed 1 of 3 supplementation strategies: either 0 ( $\mathrm{n}=19$ ), 3 ( $\mathrm{n}=$ $20)$, or $6(\mathrm{n}=20) \mathrm{kg}$ of DM concentrates/cow per day. Data were adjusted for peptidylprolyl isomerise A (PPIA) and ribosomal protein S15a (RPS15a) expression and logarithmically transformed. ${ }^{\mathrm{a}, \mathrm{b}}$ Bars with different letters are different at $P<0.001$; ${ }^{\mathrm{c}, \mathrm{d}}$ bars with different letters are different at $P<0.01$. 
GH signaling. Growth hormone signaling activates the transcription of IGF-I; therefore, while the somatotropic axis is uncoupled, IGF-I concentrations in blood become depleted (Lucy, 2008). The GHR1a transcripts in liver and IGF-I plasma concentrations were reduced in NA cows compared with NZ cows, suggesting a greater degree of uncoupling in NA cows. This is consistent with the results reported in Lucy et al. (2009). Although mean IGF-I gene expression did not differ between genetic strains, when the expression of IGF-I during wk 4 to 12 are compared between the strains, NZ cows have consistently higher IGF-I transcript amounts. Additionally, the correlations between plasma IGF-I and IGF-I mRNA concentrations suggest a strong correlation between these 2 measures, although not in the first week of lactation. The lack of correlation at wk 1 may be indicative of more variable data or posttranslational mechanisms influencing protein concentrations, as correlations from wk 4 onward suggest that the greater IGF-I concentrations in NZ cows were due to enhanced transcription of the IGF-I gene.

Free IGF-I in plasma can be degraded easily and consequently forms a ternary complex with IGFBP3 and IGFALS, proteins that protect IGF-I from degradation (Werner et al., 2008). Hence, differences in plasma IGF-I concentration also may be due to IGF-I being degraded faster in NA cows. This has been reported in nutritionally restricted beef cattle, with the authors hypothesizing the reduction was due to lower concentrations of IGFBP3 (Wu et al., 2008). Although the greater BCS loss in NA cows is a similar model to the nutritionally restricted beef cattle, transcription of IGFBP3 in liver was actually greater in NA cows, suggesting that this was not the reason for the lower concentration of IGF-I protein in NA cows in this study. Transcript measures of IGFALS were not affected by strain. From these results, it does not appear that the greater IGF-I concentrations in NZ cows are due to extra stability provided by IGFBP3 and IGFALS. In summary, GH and IGF-I concentrations in plasma and liver GHR1a transcripts indicate uncoupling of the somatotropic axis in both NZ and NA cows. However, uncoupling in NA cows is more severe, consistent with the molecular results from Lucy et al. (2009) and McCarthy et al. (2009), the difference in BCS reported here, and the BCS profiles reported by Roche et al. (2006).

\section{Supplementation Appears to Affect NZ and NA Cows in a Similar Manner}

There were no strain $\times$ diet interactions for any of the somatotropic axis molecules measured in this study. Therefore, supplementation did not lead to an earlier recoupling of the somatotropic axis in NZ compared with NA cows, results consistent with Kay et al. (2009). Body condition score and BW also were unaffected by supplementation, unlike the effect of concentrate on BCS attenuations presented by Roche et al. (2006). Body condition was not affected by strain $x$ diet interactions across the $12 \mathrm{wk}$ in contrast to 2 studies that both reported BCS loss or BCS gain in NZ cows fed supplements compared with NA cows (Macdonald et al., 2008; Lucy et al., 2009). None of the blood metabolites or genes involved in the somatotropic axis was affected by strain $\times$ diet interactions. These findings are not consistent with Lucy et al. (2009), who hypothesized an interaction because of an increase in IGF-I concentrations in the blood of NZ cows in response to supplementation, but not NA cows. Both Lucy et al. (2009) and Macdonald et al. (2008) used cows of genetic origins similar to the cows used in the current study; however, the supplementation processes were different. The BCS increases in NZ cows were reported in cows receiving 7 $\mathrm{t}$ of $\mathrm{DM} / \mathrm{cow}$ per year, but were not evident in cows on $5.6,6.1$, or $6.8 \mathrm{t}$ of $\mathrm{DM} /$ cow per year. In comparison, no $\mathrm{BCS}$ increases were reported in NA cows on up to $7.2 \mathrm{t}$ of DM/cow per year (Macdonald et al., 2008). Lucy et al. (2009) grouped those feed allowances into NZ high (6.8-7.0), NZ low (5.6-6.1), NA high (6.9-7.2), and NA low (5.8-6.1), and reported strain $\times$ diet interactions for IGF-I in the blood. The failure to detect an effect of diet on blood IGF-I concentration may reflect a lack of statistical power as there was a tendency for IGF-I concentrations to be higher in supplemented cows at several time points postcalving.

Although circulating molecules and gene expression associated with the somatotropic axis did not change in response to supplementation differently between strains, plasma insulin concentrations were affected by strain $\times$ diet interactions. From wk 7 postpartum, supplementation resulted in greater concentrations of insulin in the blood of NZ cows, but not NA cows. Carbohydrate intake, under normal conditions, results in an increase in the concentration of insulin in the blood, which then acts on various tissues to encourage glucose uptake (Saltiel and Kahn, 2001). Glucose concentrations in the blood were greater in supplemented cows compared with unsupplemented cows, but no strain effects or strain $\times$ diet interactions were observed. These data imply that glucose production and, possibly, glucose disposal mechanisms were equally effective across strains. Chagas et al. (2009) reported strain and supplementation effects when testing responses to a glucose challenge and reported that NZ cows, and those fed with supplements, had greater glucose fractional turnover rates. The authors hypothesized that cows of NZ genetic origin and cows whose diet had been supplemented with concentrates have a less severe insulin 
resistance during early lactation compared with NA HF and unsupplemented cows, respectively. The strain $x$ diet interaction in plasma insulin concentrations in the present study and the strain effects reported by Chagas et al. (2009) indicate that NA cows do not respond to increased glucose through an increase in insulin, and that NA cows may be either less insulin sensitive or less insulin responsive. Both data sets indicate that NA cows are more insulin resistant than NZ cows, as defined by Kahn (1978). In conclusion, supplementing the diet of NA and NZ cows to a level of $6 \mathrm{~kg}$ of DM/d did not result in an earlier recoupling of the somatotropic axis in NZ cows. However, a strain $\times$ diet interaction in blood insulin concentrations suggests NZ and NA cows probably respond in a different manner to supplementation, consistent with the results of glucose tolerance tests on these strains (Chagas et al., 2009) and the difference in the BCS profiles reported by Roche et al. (2006).

\section{NZ Cows Have Increased Lipogenesis Compared with NA Cows}

Gene expression of THRSP in liver was greater in NZ compared with NA cows during wk 1 to 8 postpartum. The protein produced by THRSP transcription is involved in the synthesis of fat, and transcription is activated by the concentration of carbohydrates, such as glucose, in the cell (Vaulont et al., 2000; LaFave et al., 2006). These expression data originate from liver and not adipose cells; however, they suggest that lipogenic processes are occurring at a greater rate in $\mathrm{NZ}$ cows. The NZ cows had a greater BCS during early lactation consistent with the BCS profiles presented by Roche et al. (2006), and higher plasma leptin concentrations. Leptin is a hormone involved in signaling the state of adipose tissue reserves to the rest of the body; therefore, leptin concentrations are positively associated with adipose reserves (Chelikani et al., 2009). No strain effects were evident in NEFA concentration; this is not consistent with the report of Kay et al. (2009), who demonstrated no strain differences in leptin, but greater NEFA concentrations in NA cows, in a similar study. The results of Kay et al. (2009) indicate that more lipolysis in cows of NA origin leads to the differences in BCS between the strains; the results of the current study, however, suggest greater lipogenesis in NZ cows. The absence of strain effects in BCS change is consistent with the lack of strain effects for plasma NEFA concentrations. Whereas high BCS may indicate that NZ cows do not lose as much of the energy stored in their adipose tissue and, as a result, leptin concentrations remain high compared with NA cows, the results of this study do not support strain differences in the degree of tissue mobilization. In addition, the higher THRSP expression in NZ cows, over the first $8 \mathrm{wk}$ of this study, demonstrates that de novo fat synthesis is occurring. This is a possible explanation for the wellknown differences in BCS profiles in these 2 genetic strains during lactation and is consistent with the less pronounced uncoupling of the somatotropic axis in the NZ cows.

\section{Supplementation Increases the Energy Available for Milk Production and Tissue Maintenance}

The effects of supplementation were evident at 3 levels: milk production and its components, blood metabolites, and gene expression. Milk production and its components - fat, protein, and lactose - all increased with increased supplementation, consistent with previous studies (Horan et al., 2005; Roche et al., 2006; Lucy et al., 2009). Milk protein percentage also increased with increasing supplementation in both genetic strains. This, however, contrasts with the results of Lucy et al. (2009), who reported that the increase in protein percentage from increased supplementation was limited to NZ cows. However, the differences seen in the protein percentage between the 2 studies may reflect the higher quality of supplement in the study reported here.

Blood metabolites also varied with the level of supplementation. For example, unsupplemented cows had greater circulating $\mathrm{GH}$ and lower IGF-I and glucose concentrations in blood compared with supplemented cows, but the level of supplementation had no effect. These data suggest that supplemented cows had less uncoupling of the somatotropic axis than unsupplemented cows, although transcription data show little difference in gene expression. Blood glucose concentrations also were greater in supplemented cows, as would be expected from the altered rumen fermentation with the inclusion of starch in the ration. An increase in blood glucose concentration encourages transport of glucose into cells of the surrounding tissues (Saltiel and Kahn, 2001). Uptake of glucose in the liver, in turn, activates the transcription of genes involved in fatty acid synthesis, enabling excess glucose to be used for fat synthesis (Vaulont et al., 2000). The 2 lipogenic genes activated by glucose measured in this study were THRSP and MID1IP1. These genes contain "carbohydrate-responsive elements," enabling transcription to be regulated by complexes that respond to the concentration of available nutrients (Tsatsos et al., 2008). Liver gene expression of both THRSP and MID1IP1 were increased when cows were fed $6 \mathrm{~kg}$ of $\mathrm{DM} / \mathrm{d}$, indicating that high levels of concentration supplementation increases fat synthesis and tissue reserves, consistent with the BCS profiles presented by Roche et al. (2006). 
In conclusion, supplementation in early lactation increased milk production but appeared to dampen the response to somatotropic axis uncoupling at the level of blood metabolites and liver gene expression.

\section{ACKNOWLEDGMENTS}

The authors thank and acknowledge the technical assistance of P. Aspin (Dairy NZ), the statistical expertise of B. Dow (Dairy NZ), the manuscript planning assistance of D. Lindsay (University of Western Australia), and all the help afforded by Lye farm staff. This study was funded in full by DairyNZ.

\section{REFERENCES}

Andersen, C. L., J. L. Jensen, and T. F. Ørntoft. 2004. Normalization of real-time quantitative reverse transcription-PCR data: A model-based variance estimation approach to identify genes suited for normalization, applied to bladder and colon cancer data sets. Cancer Res. 64:5245-5250.

Blache, D., R. L. Tellam, L. M. Chagas, M. A. Blackberry, P. E. Vercoe, and G. B. Martin. 2000. Level of nutrition affects leptin concentrations in plasma and cerebrospinal fluid in sheep. J. Endocrinol. 165:625-637.

Butler, S. T., A. L. Marr, S. H. Pelton, R. P. Radcliff, M. C. Lucy, and W. R. Butler. 2003. Insulin restores GH responsiveness during lactation-induced negative energy balance in dairy cattle: Effects on expression of IGF-I and GH receptor 1A. J. Endocrinol. 176:205-217.

Chagas, L. M., M. C. Lucy, P. J. Back, D. Blache, J. M. Lee, P. J. S. Gore, A. J. Sheahan, and J. R. Roche. 2009. Insulin resistance in divergent strains of Holstein-Friesian dairy cows offered fresh pasture and increasing amounts of concentrate in early lactation. J. Dairy Sci. 92:216-222.

Chelikani, P. K., D. J. Ambrose, D. H. Keisler, and J. J. Kennelly. 2009. Effects of dietary energy and protein density on plasma concentrations of leptin and metabolic hormones in dairy heifers. J. Dairy Sci. 92:1430-1441.

Downing, J. A., J. Joss, P. Connell, and R. J. Scaramuzzi. 1995. Ovulation rate and the concentrations of gonadotrophic and metabolic hormones in ewes fed lupin grain. J. Reprod. Fertil. 103:137145.

Gaines, W. L., and F. A. Davidson. 1923. Relation between percentage fat content and yield of milk. Pages 207-232 in Agric. Exp. Stat. Bull. Vol. 245. University of Illinois Agricultural Experiment Station, Champaign.

Gluckman, P. D., J. J. Johnson-Barrett, J. H. Butler, B. W. Edgar, and T. R. Gunn. 1983. Studies of insulin-like growth factor-I andII by specific radioligand assays in umbilical cord blood. Clin. Endocrinol. (Oxf.) 19:405-413.

Grala, T. M., J. K. Kay, C. G. Walker, A. J. Sheahan, M. D. Littlejohn, M. C. Lucy, and J. R. Roche. 2010. Expression analysis of key somatotropic axis and liporegulatory genes in ghrelin- and obestatininfused dairy cows. Domest. Anim. Endocrinol. 39:76-83.

Hales, C. N., and P. J. Randle. 1963. Immunoassay of insulin with insulin-antibody precipitate. Biochem. J. 88:137-146.

Harris, B. L., J. M. Clark, and R. G. Jackson. 1996. Across-breed evaluation of dairy cattle. Proc. N.Z. Soc. Anim. Prod. 56:12-15.

Hellemans, J., G. Mortier, A. De Paepe, F. Speleman, and J. Vandesompele. 2007. qBase relative quantification framework and software for management and automated analysis of real-time quantitative PCR data. Genome Biol. 8:R19.11-R19.14.

Horan, B., P. Dillon, P. Faverdin, L. Delaby, F. Buckley, and M. Rath. 2005. The interaction of strain of Holstein-Friesian cows and pas- ture-based feed systems on milk yield, body weight, and body condition score. J. Dairy Sci. 88:1231-1243.

Kahn, C. R. 1978. Insulin resistance, insulin insensitivity, and insulin unresponsiveness: A necessary distinction . Metabolism 27:18931902.

Kay, J. K., C. V. C. Phyn, J. R. Roche, and E. S. Kolver. 2009. Extending lactation in pasture-based dairy cows. II: Effect of genetic strain and diet on plasma hormone and metabolite concentrations. J. Dairy Sci. 92:3704-3713.

LaFave, L. T., L. B. Augustin, and C. N. Mariash. 2006. S14: Insights from knockout mice. Endocrinology 147:4044-4047.

Lucy, M. C. 2008. Functional differences in the growth hormone and insulin-like growth factor axis in cattle and pigs: Implications for post-partum nutrition and reproduction. Reprod. Domest. Anim. 43:31-39.

Lucy, M. C., G. A. Verkerk, B. E. Whyte, K. A. Macdonald, L. Burton, R. T. Cursons, J. R. Roche, and C. W. Holmes. 2009. Somatotropic axis components and nutrient partitioning in genetically diverse dairy cows managed under different feed allowances in a pasture system. J. Dairy Sci. 92:526-539.

Macdonald, K. A., G. A. Verkerk, B. S. Thorrold, J. E. Pryce, J. W. Penno, L. R. McNaughton, L. J. Burton, J. A. S. Lancaster, J. H. Williamson, and C. W. Holmes. 2008. A comparison of three strains of Holstein-Friesian grazed on pasture and managed under different feed allowances. J. Dairy Sci. 91:1693-1707.

McCarthy, S. D., S. T. Butler, J. Patton, M. Daly, D. G. Morris, D. A. Kenny, and S. M. Waters. 2009. Differences in the expression of genes involved in the somatotropic axis in divergent strains of Holstein-Friesian dairy cows during early and mid lactation. J. Dairy Sci. 92:5229-5238.

NRC. 2001. Nutrient Requirements of Dairy Cattle. 7th ed. Natl. Acad. Press, Washington, DC.

Rhoads, R. P., J. W. Kim, B. J. Leury, L. H. Baumgard, N. Segoale, S. J. Frank, D. E. Bauman, and Y. R. Boisclair. 2004. Insulin increases the abundance of the growth hormone receptor in liver and adipose tissue of periparturient dairy cows. J. Nutr. 134:1020-1027.

Roche, J. R., D. P. Berry, and E. S. Kolver. 2006. Holstein-Friesian strain and feed effects on milk production, body weight, and body condition score profiles in grazing dairy cows. J. Dairy Sci. 89:3532-3543.

Roche, J. R., P. G. Dillon, C. R. Stockdale, L. H. Baumgard, and M. J. VanBaale. 2004. Relationships among international body condition scoring systems. J. Dairy Sci. 87:3076-3079.

Roche, J. R., N. C. Friggens, J. K. Kay, M. W. Fisher, K. J. Stafford, and D. P. Berry. 2009. Invited review: Body condition score and its association with dairy cow productivity, health, and welfare. J. Dairy Sci. 92:5769-5801.

Saltiel, A. R., and C. R. Kahn. 2001. Insulin signalling and the regulation of glucose and lipid metabolism. Nature 414:799-806.

Tsatsos, N. G., L. B. Augustin, G. W. Anderson, H. C. Towle, and C. N. Mariash. 2008. Hepatic expression of the SPOT 14 (S14) para$\log$ S14-related (Mid1 interacting protein) is regulated by dietary carbohydrate. Endocrinology 149:5155-5161.

Vandesompele, J., K. De Preter, F. Pattyn, B. Poppe, N. Van Roy, A. De Paepe, and F. Speleman. 2002. Accurate normalization of real-time quantitative RT-PCR data by geometric averaging of multiple internal control genes. Genome Biol. doi:research0034. 0031-0034.0011.

Vaulont, S., M. Vasseur-Cognet, and A. Kahn. 2000. Glucose regulation of gene transcription. J. Biol. Chem. 275:31555-31558.

Werner, H., D. Weinstein, and I. Bentov. 2008. Similarities and differences between insulin and IGF-I: Structures, receptors, and signalling pathwyas. Arch. Physiol. Biochem. 114:17-22.

Wildman, E. E., G. M. Jones, P. E. Wagner, R. L. Boman, H. F. Troutt Jr., and T. N. Lesch. 1982. A dairy cow body condition scoring system and its relationship to selected production characteristics. J. Dairy Sci. 65:495-501.

Wu, M., A. Wang, G. C. Bernard, J. B. Hall, W. E. Beal, R. Michael Akers, Y. R. Boisclair, and H. Jiang. 2008. Increased degradation of insulin-like growth factor-I in serum from feed-deprived steers. Domest. Anim. Endocrinol. 35:343-351. 